\title{
Philosophic (In)Felicity: Protean Narrativity
}

Amir Abbas Moslemi

Tehran, Iran

E-mail address: a.a.moslemi@gmail.com

Keywords: James Joyce, J.L. Austin, analytic philosophy, (in)felicity, language, school of 'ordinary language philosophy', Aristotle

\begin{abstract}
Philosophic contingency embedded in James Joyce's avant-garde novel, ranging from Aristotelian notion of mimesis to the possibility of a Marxian reading, stemming from Hegel's dialectic, added to the linguistic pragmatics, pave the way to focus on the process of realization and mental performance by a leading contemporary philosopher of analytic philosophy, J.L. Austin, as an epistemological triggering in the course of implication through a narrative, here Proteus, teleologically speaking, resulting a meta-utterance in a broader scale, much far from constative type, a metaphorical narration, elaborating on cultural agency, while paraphrasing the languagebased relativity of collective identity and complexity of Austin's speech act theory, in terms of (in)felicitous conditions, rooted in the success of the communicative intention of the narrator, here Stephen Dedalus, maybe the most wonderful advanced guard of narratology in interior monologue.
\end{abstract}

BLOOM

(Placing his right hand on his testicles, swears).

So may the Creator deal with me.

All this 'I promise' to do.

(James Joyce, Ulysses)

\section{Introduction}

A leading figure in analytic philosophy, John Langshaw Austin (1911-1960), believes that Bloom in "all this I promise to do" (Joyce Ulysses 482) is not uttering evaluativley nor descriptively, but just acting. Those meanings that have truth values and express propositions are evaluative. Descriptive utterances are cognitive since they have truth values, whereas evaluative ones are non-cognitive which means they express attitudes. This distinction is not new. What Austin brought us is that 'I promise', and a good many deal of other utterances like this, in the ordinary language, are not a part of the former nor the latter. By attacking this division, Austin pushes philosophy, into a new realm of developing a meticulous reevaluation of non-philosophical language, to shed more light on the distinctions we have, in our cut-and-dried life.

\section{Austin, Russell, Wittgenstein}

Ordinary life has its ordinary language toward which, there are two different philosophical attitudes. On one hand, Austin believes that this inherited language that we use in our life is in most areas a sophisticated and totally complex and subtle instrument that can help us clarify philosophical notions, by putting itself under close scrutiny, and on the other hand, Russell maintains that philosophy draws its problems from natural science, that its task is the analysis and explanation of the principals and concepts of natural science, and that the essence of philosophy is logic, the logical analysis of language (Rosenthal Russell) (Landini 147-188), and Wittgensteinwhen writing his Tractus Logico-Philosophicus ${ }^{1 \mathrm{i}}(1922)$ - insisted on the opposite, that ordinary

\footnotetext{
${ }^{1}$ Latin for Logical philosophical Treatise
} 
language "was the mere primitive, confused and confusing surface beneath which theorists were to seek the proper forms of both language and logic" (Craig 759).

\section{Speech Act Theory}

What we typically perform, as we speak, is the focus of Austin's theory of speech acts. Introducing the word 'performative', Austin tries to review the whole history of philosophy to remind us, what is usual is to find out whether any utterance is true or false, or what he calls 'constatives'. Utterances that are not truth-evaluable are performative utterances. Those which are in order- nothing is wrong with them, are felicitous and those with which something is wrong are infelicitous. As a performative is uttered, something is done, the locution. Hence, a locutionary act is saying something meaningful, whereas saying something meaningful for some purpose is an illocutionary act. Perlocutionary acts have an effect on those who hear what is said. Austin is much more meticulous than others when encountering "things like imperatives, the expression of wishes and exclamations", till he castigates logical positivism for defaming the taxonomical framework of non-referential utterances. Taking "statements, reports or descriptions" as referential ones, he seeks to go beyond what is usual and remove the label of "nonsense" from those still not classified by philosophers. Touching literature, Austin quotes the first line of an untitled poem (1633) by John Donne, Go and Catch a Falling Star, to clarify that "considerations of this kind apply to any utterance at all, not merely to performatives" (Austin Philosophical 233-241).

\section{Bit of a Marxian Fever}

The objectivity of the outlook of Mirsky in 1933 when he wrote "Joyce is the literary representative of the Irish petty bourgeoisie" (Mirsky 31) can be traced back to 1917 when New Age published an unsigned review in July $12^{\text {th }}$,

...he [Joyce] fears to suffer, and will not therefore, put himself in the place of his hero; he will record with wonderful fidelity, and frequently with remarkable dramatic skill, what happened around or to Stephen Dedalus, but as it is all objectively viewed and objectively rendered, the character has no continuum, no personality" (254).

Proteus, the third chapter of Ulysses, elaborates on Stephen, endlessly moving between the twin poles of objectivity and subjectivity. What is rendered through his thoughts, mingles with what he is seeing with by material body, which is also feared to be seen as an object, "who watches me here?"; "Can't see! Who's behind me?" (Joyce Ulysses 48). Shape shifting from a speculator to a spectator, it seems as if subject and object are the same- specre is the Latin root for 'see, look'.

Going back into history of a word, very often into Latin we come back pretty commonly to pictures or models of how things happen or are done. These models maybe fairly sophisticated and recent, as is perhaps the case with 'motive' or 'impulse' but one of the commonest and most primitive types of model is one which is apt to baffle us through its vey naturalness and simplicity (Austin Plea 29).

The main standpoint, one can find the object-subject relation, is Materialism against Idealism. The union of the object and subject in materialism never ends to their being identical. Whether natural or societal, the existence of the object is prior to its subject, wholly independent; the inner life of Stephen, Stephen vis-à-vis cockle pickers, Cock Lake and so on. Stephen's eyes are open, not yet closed. "Ineluctable modality of the visible" and, out there, what are they?

The main point is not, that they are, but what they are, and whether or not their content is true. It does no good to the things to say merely that they have being. 


\begin{abstract}
What has being, will also cease to be when time creeps over it. It might also be alleged that subjective idealism tended to promote self-conceit. But surely if a man's world be the sum of his sensible perceptions, he has no reason to be vain of such a world. Laying aside therefore as unimportant this distinction between subjective and objective, we are chiefly interested in knowing what a thing is: i.e. its content, which is no more objective than it is subjective (Hegel 43).
\end{abstract}

Idealist philosophy holds that reality and reason are the same (Craig Hegel). The identicality of the subject and object against their separate existences makes Stephen close his eyes to start his experiment "shut your eyes and see". The process is Aristotelian, though. Stephen finds the material world or space as "what you damn well have to see" (Joyce Ulysses 186). Marxianly speaking, "We are all situated historically and socially, and our historical and social contexts "determine" or shape our lives. This is true of literature as it is true of human beings..." (Rivkin and Ryan 234). Thought and sight in accordance with mind act together to create the Aristotelian phase of the vision. Is Stephen seeing or is he seen? How is he 'mediating' to clarify an exact justification of whereabouts of his speculation through the process of seeing or being seen? It is not the single effect of interior monologue as a technique which does give us the answer to these questions. The apparition of a vague philosophical personality, is the least, and just an initiative outcome of a fair reading, which is failed by the nameless writer of the New Age. The continuum he is looking for is the somersault Stephen is experiencing, between flux and fixity, space and time, actuality and imagination (Johnson 782).

Bourgeois decadence is the starting point from which various Marxian nuances evolved Joyce-wise, initiating critics like Radek who called Joyce "the hero of contemporary bourgeois literature" (Radek 2) then, Miller-Budnitskaya's "the psychology of the average man", resulting T. Farrell to ask: "Is a Marxist warranted in judging from so philistine a viewpoint...?" (Farrell 98).

\title{
5. Propositional Content
}

Austin maintains that not every time the verb 'promise' is used we are uttering a performative. Consider a Communist on Joyce: "Joyce acquires social significance. He promises [emphasis added] his audience that he will lead them to the depth that they long to fathom, but he excludes those things the penetration of which might lead to the revolution" (Gertsfelde 3). "Sie wissen das nicht, aber sie tun es ${ }^{2 i i}$,

According to Austin, when we say, 'he promises' we are reporting somebody's 'I promise', therefore, 'I promise' is a performative since the action of performing a promise, is present in it; note the usage of first person singular present indicative active, but when the tense is shifted backwards like 'I promised that...', again, we are reporting not performing. The Marxian critic is attaching a report to Joyce that he does so and so. Bloom with hand on his testicles, utters a performative force not a report. "Let us distinguish between acting intentionally and acting deliberately or on purpose, as far as this can be done by attending to what language can teach us" (Austin Philosophical 273). György Lukács, Hungarian Marxist philosopher, aesthetician, literary historian, and critic defines the novel as "the epic of a world that has been abandoned by God" (Lukács Theory 23); Abram's reading elaborates on bourgeois epic as "all novels that reflect the social reality of their capitalist age on a broad scale... [Emphasis added] (Abrams 78). Cristopher Bode's concept of the 'core business' of the novel, is not far from Lukács's 'totality of being', since he writes "the novel's core business has always been to offer and display "possibilities of the generation and construction of meaning" (Bode 256). The heavy reliance of individual utterances on "background conditions" was discussed by Ferdinand de Saussure and Wittgenstein. The latter also claimed for the necessity of meaning to be described, to "place narrative as a socially symbolic act" (Moslemi 49). The linguistic proximity of the schemata Joyce prepared for Proteus and Proteus itself call for the "background" defamiliarization of philology, as the science focused by Joyce, to

\footnotetext{
${ }^{2}$ German for "they do not know it, but they are doing it".
} 
utter a narrative, which in a broader scale, is illocutionary; moreover, a metamorphosis is undergone as soon as the hiatus of a perlocutionary force is aptly filled as Austin elaborates

\begin{abstract}
that any utterance which is performative could be reduced or expanded or analyzed into one of these two standard forms; beginning 'I...' so and so, or beginning 'You (or he) hereby...' so and so. If there was any justification for this hope to make a list of all the verbs which can appear in these standard forms and then we might classify the kind of acts that can be performed by performative utterances (Austin Philosophical 234).
\end{abstract}

\title{
6. Double Explicit Performatory
}

Stephen's "shut your eyes and see" (Joyce Ulysses 37) is classified by Austin as 'explicit performative' whereas a primary performative utterance lacks the consent "whether we are ordering you or entreating you or, one another of many other subtly different acts which, in sophisticated primitive language, are very likely not yet discriminated. Never does Jakob Boheme mean to place Signatura Rerum ${ }^{3}$ before "I am here to read" to suggest that the world exists prior to Stephen. 'Here', compared to Austin's 'hereby' before the imperative "shut your..." makes, a double explicit performative. The immediacy covert in the construction of a state in which, no sooner than the reader, who is also the perceiver in context, is ordered to shut his/her eyes, "and see", again, handles another performatory. Taking "here" as Austin's "hereby", added to the distinction Austin makes between "I order you to shut the door" and "Shut the door", we clearly see Joyce is creating a narrative in which, Stephen is performing a performative, so subtle that at first glance, the only rationalization would suggest a poetical escape from simple prose, which Austin fears us to "overestimate the unsophistication of (its) primitive language" instead, paying close attention to "the tone of voice, cadence, gesture" in order to find "the nature of the circumstance", and then "the context" in which the utterance is issued. Since a poetical escape is not rendered as a non-figurative reference to define a particular narrative, it is suggested that a "precise grammatical and lexical criteria" would suffice, but the truth is, that "it over simplifies the literary problems by carrying too far the correspondence between spoken discourse and silent thought. Speech is by definition always verbal, but thought is a matter of dispute, concerning consciousness, called "other mind stuff" by William James, it can be narrated directly or indirectly, but not quoted (Cohn 10). What Austin does is to undermine positivists' model of knowledge, to clarify explicitly claims about the world, and the social relations that we find in the ordinary language, not a purified one. Therefore, Stephen is not quoting his thought, he is perceiving world, contemplating through Aristotle, the inescapability of the material world, as Žižek puts it: “...the task of philosophy is not to put answers, but to show how the way we perceive a problem can be itself part of the problem (Žižek 1:07), and, in particular, that aspect of it which is perceptible through the sense of sight.

\section{Rere Regardant}

From " the inescapable nature of that which can be seen", in the opening, we get to the final "rere regardant" (Joyce Ulysses 51), which is a felicitous gesture of Viconian looking backwards, while an actual stuttering of the tongue fulfills the linguistic felicity of the performative in the broader scale. The whole narrative, generally, portrays the infelicity of Stephen's voice, trapped in Dublin, as Proteus trapped and fixated by Menelaus. Proteus is telling everything- in the Homeric level- because unhappily he is betrayed by his daughter ... (Johnson 782-3). What Stephen typically performs as he speaks-the focus of Austin's theory of speech act, to put it by Vico, is to stutter, both in speaking and in thinking, or even finally in expression, "rere regardant". As a presupposition of a forward to "Bygmester Finnegan, of the Stuttering Hand' (Joyce Finnegans Wake 4), as an exordium to a voice yet not discovered, or to put it in a broader scale, as an exordium to a new discourse. The social taxonomical status of Ulysses, the so-called bourgeois categorization,

\footnotetext{
${ }^{3}$ Latin for "signature of all things"
} 
alienation in its Marxian term, écriture féminine, Kristeva's reading of Bakhtin (Kristeva 37), and even McHale's outstanding Coda on Joyce's endings, distinction between epistemological and ontological concerns of postmodern literature (McHale 233), all, might be able to be explained under Austin's speech act theory, since they are deeply rooted in the epistemological nuances. "Rere Regardant" is the manifestation of an inner contradiction between Protean poles, floating from Homeric parallels to Dublin's 'tawdry townsmen'. The more Stephen tries to change the outcome of his perlocutionary force, the more struggle he beholds (in)felicitously, causing him seep deeper, down his gaze; moreover, we have his thought, as he stares, desiring to paraphrase his civic consciousness, trapped in a place for which he fights, contradictorily, both to live and depart.
A place belongs to the one who has most deeply
loved it, they said, has hoped in it beyond
its self-corruption. The land, people, the city
...
He could not find
a door to open. He did not know a soul (Moritz 119).

\section{Conclusion}

"Within the social construction of selfhood "man gladly accepts as his authority Hegel's idea iii according to which the citizen acquires his ethical dignity in transcending himself towards the universal, but as a primitive individual he has a right to desire and pleasure" (Beavoir second 646). The kernel of this philosophy which is taken to be "innocent and child-like fancies" (Marx and Engels 1), is a "purely metaphysical construct" (Lukács History xxiii) rooted in consciousness. "The Absolute is infinite life, and love is the consciousness of the unity of this life, of unity with the infinite life itself and of unity with other men through this life" (Copleston 164). Although Stephen is mediating on Aristotle, he cannot accept the Eleatic School, "that the world was fundamentally unknowable by humans" (Woodfin and Groves 30); he wants to know it; hence, his question, which Heidegger calls the "piety of the question"iv , back and forth displaced in itself/ by itself, comes before the displaced constative, manages to get to "the performativity of the event", turns the question into an ontological (Woolfreys 250).

$i$ "In this aphoristic and difficult book he presents the view that the only meaningful use of language is a picture of empirical, scientific fact; otherwise language will be tautological, as in logic and mathematics, or nonsensical as, in metaphysics and judgments of value" (Drabble Wittgenstein).

ii 'Ideology' (Marx 88).

iii Phenomenology of Sprit (1807) advanced the notion that selfhood is socially constructed; civic consciousness is a stage on the route to full self-consciousness.

${ }^{\text {iv }}$ For a rigorous complication of Heidegger's question, see Derrida's Of Spirit...

\section{References}

[1] Abrams, M. H. A Glossary of Literary Terms. Boston, Mass. [u.a.: Heinle \& Heinle, 2001. Print.

[2] Austin, J. L., and G. J. Warnock. Sense and Sensibilia,. Oxford: Clarendon, 1962. Print.

[3] Austin, J. L.

a. How to Do Things with Words. Cambridge: Harvard UP, 1962. Print.

b. Austin, J. L. Philosophical Papers. Oxford: Clarendon, 1961. Print.

c. "A Plea for Excuses." Proceedings of the Aristotelian Society New Series, Vol. 57 (1956 - 1957) Reprinted in 1961. Print.

[4] Beauvoir, Simone. The Second Sex. New York: Knopf, 1953. Print. 
[5] Böhme, Jakob, and John Ellistone. Signatura Rerum, Or, The Signature of All Things Shewing the Sign and Signification of the Severall Forms and Shapes in the Creation, and What the Beginning, Ruin, and Cure of Every Thing Is ... London: Printed by John Macock for Gyles Calvert ..., 1651. Print.

[6] Bode, Christoph, and James Vigus. The Novel : An Introduction. Chichester, West Sussex; Malden, MA: Wiley-Blackwell, 2011. Print.

[7] Chappell, V. C., Norman Malcolm, Gilbert Ryle, J. L. Austin, Benson Mates, and Stanley Cavell. Ordinary Language : Essays in Philosophical Method. Englewood Cliffs, N.J.: Prentice-Hall, 1964. Print.

[8] Cohn, Dorrit. Transparent Minds : Narrative Modes for Presenting Consciousness in Fiction. Princeton, N.J.: Princeton UP, 1978. Print.

[9] Copleston, Frederick. A History of Philosohy. 7 7. London: Continuum, 2003. Print.

[10] Craig, Edward. The Shorter Routledge Encyclopedia of Philosophy. London; New York: Routledge, 2005. Print.

[11] Derrida, Jacques. Of Spirit: Heidegger and the Question. Chicago: University of Chicago Press, 1991. Print.

[12] Donne, John, and John T. Shawcross. The Complete Poetry of John Donne. Garden City, N.Y: Anchor Books, 1967. Print.

[13] Drabble, Margaret. The Oxford Companion to English Literature. Oxford [England]: Oxford UP, 2000. Print.

[14] Farrell, James. T. "Reply to Mirsky and Radek." 1936. Literary Criticism (1936) : pp. 83-5, 97-106. Print.

[15] Gertsfelde, V. “A Communist on Joyce.” Living Age, cccxlvii. November 1934. Print

[16] Hegel, Georg Wilhelm Friedrich, and Rogers D. Spotswood Collection. Hegel, the Essential Writings. New York: Harper \& Row, 1974. Print.

[17] Hegel, Georg Wilhelm Friedrich,, Théodore F. Geraets, W. A. Suchting, and H. S. Harris. The Encyclopaedia Logic, with the Zusätze : Part I of the Encyclopaedia of Philosophical Sciences with the Zusätze. Indianapolis: Hackett, 1991. Print.

[18] Joyce, James, and Jeri Johnson. Ulysses. Oxford; New York: Oxford UP, 1993. Print.

[19] Joyce, James.

a. Ulysses. New York: Modern Library, 1992. Print.

b. Finnegans Wake. New York: The Viking Press, 1939. Print.

[20] Kristeva, Julia. Kristeva Reader The. Ed.Toril Moi. New York: Columbia University Press, 1986. Print.

[21] Landini, Gregory. Wittgenstein's Apprenticeship with Russell. Cambridge, UK: Cambridge University Press, 2007. Internet resource.

[22] Lodge, David. Modern Criticism and Theory : A Reader. Harlow: Pearson, 2010. Print.

[23] Lukács, György.

a. History and Class Consciousness: Studies in Marxist Dialectics. Cambridge, Mass: MIT Press, 1971. Print.

b. The Theory of the Novel: A Historico-Philosophical Essay on the Forms of Great Epic Literature. Cambridge, Mass: M.I.T. Press, 1971. Print. 
[24] MacHale, Brian. Postmodernist Fiction. New York; London: Methuen, 1987. Print.

[25] Marx, Karl, and Friedrich Engels. The German Ideology. New York: International Publishers, 1967. Print.

[26] Marx, Karl. Grundrisse: Foundations of the Critique of Political Economy. New York: Vintage Books, 1973. Print.

[27] McQuillan, Martin. The Narrative Reader. London [etc.]: Routledge, 2000. Print.

[28] Mirsky, D. S. "Joyce and Irish literature." tran. by David Kinkead. New Masses, X-XI (3 April 1934) : 31-. 34. Print.

[29] Moritz, A. F. "Place.” Poetry. Vol. 188 Issue 2. (May2006). Print.

[30] Moslemi, Amir Abbas. "An Exordium to a Promise." International Letters of Social and Humanistic Sciences Vol. 54 (Jun 2015): pp. 45-52. SciPress. Bach, Switzerland. Print.

[31] Radek, Karl. "James Joyce or Socialist Realism?" Contemporary World Literature and the Tasks of the Proletariat. 1934. Print.

[32] Rivkin, Julie, and Michael Ryan. Literary Theory : An Anthology. Malden, MA [etc.]: Blackwell, 2010. Print.

[33] Rozental', M. M., and P. IUdin. A Dictionary of Philosophy,. Moscow: Progress, 1967. Print. [] Wittgenstein, Ludwig. Tractatus Logico-philosophicus. The German Text Logischphilosophische Abhandlung, . New York: Humanities, 1961. Print.

[34] “Unsigned review." New Age. 12 July 1917, xxi, n.s. No. 11, 254

[35] Wolfreys, Julian. Introducing Literary Theories: A Guide and Glossary. Edinburgh: Edinburgh Univ. Press, 2006. Print.

[36] Woodfin, Rupert, and Judy Groves. Introducing Aristotle : A Graphic Guide. London: Icon, 2013. Print.

[37] "Žižek- Year of Distraction - YouTube.". Web. 